

DEN NORSKE LEGEFORENING

\title{
Anne-Lise Stadskleiv
}

MINNEORD

ANNE LINDSTAD

ELISABET TØNSBERG

INGEBJØRG ULVESTAD

INGER-JOHANNE AARSETH

RØNNAUG ̊̊SGARD

SVETLANA MITIC

TORI ANNE RøVIK

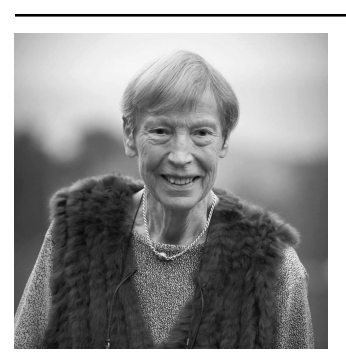

Anne-Lise Stadskleiv er død, 74 år gammel. Hun sovnet stille inn 20. juni etter over fem år med kreftsykdom.

Hun vokste opp i Askim sammen med en yngre søster. De hadde fire eldre halvsøsken, og en av disse kom senere til å bety mye for Anne-Lise. Etter artium dro hun i 1963 til Nederland, der hun tok første del av medisinstudiet. Hun kom tilbake til Oslo i 1967, og ble cand.med. i 1970. I studietiden giftet hun seg med Kåre, og de fikk døtrene Kristine og Ingunn. Hun videreutdannet seg til spesialist i allmennmedisin, og arbeidet noen år som allmennlege i Oslo. Deretter spesialiserte hun seg i psykiatri. I en årrekke arbeidet hun på Grorud DPS, der hun fikk betydelig erfaring i behandling av pasienter med alvorlige psykoselidelser. Hun har satt dype spor etter seg som en av de beste klinikerne innen psykosefeltet.

Vår legegruppe startet på Ahus for 30 år siden. Anne-Lise var den eldste av oss. Med sin faglighet, klokskap og menneskelighet var hun i mange situasjoner som en klippe for oss. Hun hadde en ro og en egen evne til å lytte og gå inn i den andres sted. På den måten skapte hun et trygt rom omkring seg. Dette gjorde hun også i sosiale sammenhenger, blant annet på de mange reisene vi fikk oppleve sammen. For Anne-Lise var tilknytningen til 
Frelsesarmeen viktig helt fra ungdomstiden. De siste årene har hun og familien også vært tilknyttet bistandsarbeid som Frelsesarmeen i Uganda drev.

Vi minnes Anne-Lise i takknemlighet. Våre tanker går til Kåre og døtrene med familier.

Publisert: 13. november 2018. Tidsskr Nor Legeforen. DOI:10.4045/tidsskr.18.0721

(C) Tidsskrift for Den norske legeforening 2020. Lastet ned fra tidsskriftet.no 